\title{
Forced eruption with customized resin tube appliance
}

\author{
So-Young Kim ${ }^{1}$, Sang-Ho Lee ${ }^{1,2}$, Nan-Young Lee ${ }^{1,2 *}$, and Myeong-Kwan Jih ${ }^{1,2}$ \\ ${ }^{1}$ Department of Pediatric Dentistry, School of Dentistry, Chosun University, Gwangju 61452, Republic of Korea \\ ${ }^{2}$ Oral Biology Research Institute, Chosun University, Gwangju 61452, Republic of Korea
}

(Received Nov 9, 2017; Revised version received Dec 13, 2017; Accepted Jan 9, 2018)

\begin{abstract}
There are various forms of dental trauma that occur in childhood. In the subgingivally crown-root fracture case, forced eruption has been depicted as one of the most conservative treatments. Generally, the forced eruption is done by using wires, power chains, elastic threads, or using removable appliances and elastic. However, due to the characteristics of pediatric patients, it is difficult to obtain the patient's cooperation and maintain clean oral hygiene status. As an alternative, forced eruption using MTA (Mini-Tube Appliance) can be proposed. This case report describes two cases of subgingivally crown-root fracture, which were treated with modified MTA to form a customized resin tube to perform a treatment more aesthetic, rapid, and stable.
\end{abstract}

KEY WORDS: Biologic width, Crown-root fracture, Forced eruption, Mini-Tube Appliance (MTA), Subgingivally fracture

\section{서 론}

소아청소년의 외상성 손상에는 치아 성숙도 및 외상의 정도에 따라 다양한 치료법이 적용될 수 있는데 특히, 심 미적인 위치에 있는 치아의 외상은 치아가 심미적, 기능적 상태를 유지할 수 있도록 하기 위해 많은 요인이 고려되 어야 한다[1]. 외상에 의한 치아의 파절은 $17.5 \%$ 의 이환율 을 보이며 이 중 치관치근 파절은 약 $5 \%$ 정도로 보통 전 치부에 가해지는 직접적인 외상에 의해 발생된다[2,3]. 치 관치근 파절과 같이 치주조직 또는 치조골 하방으로 치아 가 파절되면 수복치료 시 큰 어려움이 생긴다[4].

치관치근 파절된 치아의 수복을 위해서는 생물학적 폭 경의 유지가 중요한 요소이다. 만약 파절선이 생물학적 폭 경을 침범하지 않는 범위에 있다면 파절편의 재부착이 가 능할 수 있다. 하지만 계획된 수복물이 생물학적 폭경을 침범할 위험이 있는 경우, 이를 증가시키기 위한 임상적 치관연장술이 고려되어야한다. 생물학적 폭경은 Gupta 등 [5]에 의해 언급된 개념으로 치은구에서 치주조직으로의 세균 감염을 방어하기 위해 필요로 하는 폭으로 수복물이

\footnotetext{
*Corresponding author: Nan-Young Lee

Department of pediatric dentistry, School of Dentistry, Chosun University, 309 Phimundaero, Dong-gu, Gwangju 61452, Republic of Korea Tel.: +82-62-220-3867, Fax: +82-62-225-8240

E-mail: Nandent@chosun.ac.kr
}

생물학적 폭경을 침범하게 되면 감염, 수복물에 의한 결합 조직섬유의 파괴에 의한 부착 소실, 골소실이 발생하게 된 다[6]. 따라서 수복 처치를 할 경우 이 생물학적 폭경을 파괴 하거나 기계적으로 침습하지 않도록 하는 것이 중요하다.

이러한 생물학적 폭경을 증가시키는 방법으로 치조골 수술을 포함한 근단변위판막술, 외과적 정출술 또는 의도 적 재식술, 교정적 정출술 등이 있다[3,7,8]. Dentogingival complex와 각화치은이 충분한 경우에는 연조직이 충분하 므로 외사절개를 통한 치은절제술만으로 치료가 가능하다. 하지만 dentogingival complex 양과 무관하게 각화치은이 $2 \mathrm{~mm}$ 이하로 부족한 경우에는 외사절개를 통한 치은절제 가 불가능하며 내사절개를 통해 근단변위판막술을 시행해 야한다[9]. 이와 같은 외과적 치관연장술은 상악 전치부와 같이 심미적으로 중요한 부위에서는 추천되지 않고 외과 적 정출술 또는 교정적 정출술을 통한 생물학적 폭경의 획 득을 추천한다.

외과적 또는 교정적 정출술의 첫 번째 목적은 최종 수 복시 건전한 치주 조직을 제공하고 생물학적 폭경의 확보 를 통해 환자가 치아를 쉽게 유지, 관리할 수 있도록 하는 것이다[1]. 외과적 정출술은 치아의 파절선과 골과의 관계 를 확인한 후 치아를 탈구시켜 원하는 위치까지 정출시키 는 방법으로 빠르고 간단하게 시행할 수 있지만 치료 도 중 치주인대 세포의 손상이 있을 수 있다는 단점이 있다. 이보다 보존적인 방법으로 교정적 정출술을 선택할 수 있 다. 이 치료법은 심미적으로 중요한 치아에서 선택될 수 
있는 술식으로 더 나은 치관치근 비율과 외과적 술식만 시 행한 경우보다 더욱 심미적인 결과를 제공하여 우선적으 로 추천되는 술식이다[5].

교정적 정출술은 통상적으로 가철식 장치와 고무줄 또 는 브라켓과 와이어를 이용하여 진행될 수 있는데[10] 이 러한 기존의 방법은 치료 중 발생 가능한 불편함, 구강위 생관리의 어려움, 협조도의 필요와 같은 문제점이 있다[4]. 이와 같이 기존에 사용되는 방법들의 단점들을 극복하기 위 해 전치부 부분교정에 사용되는 MTA (Mini Tube Appliance) 를 이용할 수 있을 것이다.

$\mathrm{MTA}$ 는 $3 \mathrm{~mm}$ 정도 크기의 미니튜브를 사용해 이물감이 나 통증이 거의 없고 빠르면 6주, 평균 3-6개월 정도로 교 정기간이 짧다[11]. 그리고 기존 브라켓에 비해 탈락률이 낮으며 심미적이다[11,12]. 또한 마찰저항이 적어 light force의 와이어만으로도 빠른 이동이 가능하다는 장점이 있다[11]. 하지만 시판되고 있는 MTA는 가격이 고가여서 이를 대체할 만한 방법들이 제안되었다. 그 예 중 하나가 $3 \mathrm{~mm}$ 길이로 절단한 시린지 팁을 사용하는 것으로 니들 을 절단하여 튜브 대용으로 사용하는 방법이다. 다른 방법 으로는 elastic thread를 사용해 튜브를 대신할 수 있는 홀 을 직접 형성하는 방법이다. 두 가지 방법은 재료가 저렴하 고 구하기 쉬워 간편하게 사용할 수 있다는 장점을 가지고 있 다. 본 증례에서는 기존에 사용되는 교정적 정출술의 문제점 을 극복하기 위해 두 가지 modified MTA를 통해 Customized resin tube를 형성하여 교정적 정출술을 시행한 증례를 소 개하고자 한다.

\section{증례보고}

\section{증례 1}

2016년 08월 상악 좌측 중절치의 외상에 의한 치은연하 파절을 주소로 14 세 남아가 조선대학교 치과병원 소아치 과에 내원하였다. 내원 당시 임상 및 방사선학적 검사 상 순측에서 치은연상, 구개측에서 치은연하 파절 상태로 치 수침범이 있는 치관치근파절로 진단되었다(Fig. 1). 치수치 료 후 정출량을 좀 더 가시적으로 확인할 수 있도록 임시 치관심미수복술을 시행하였다(Fig. 2). 외상 3개월 후 교정 적 정출술을 위해 Customized resin tube를 형성하였다. 간 접 부착방법으로 시린지팁을 이용하여 Passive Bracketing 을 시행하였고 이는 $.016 \times .022 \mathrm{SS}$ rectangular wire 삽입 에 용이한 직경을 얻기 위함이다. 그 후, 정출력을 제공하 기 위한 Customized resin tube는 elastic thread를 이용해 직접 형성하고 .012 niti wire를 삽입하였다(Fig. 3). 주기적 으로 정출 정도를 확인하고(Fig. 4) 치료 중 교합간섭이 발 생하지 않도록 반복적인 절단면 삭제를 시행했다. 2개월
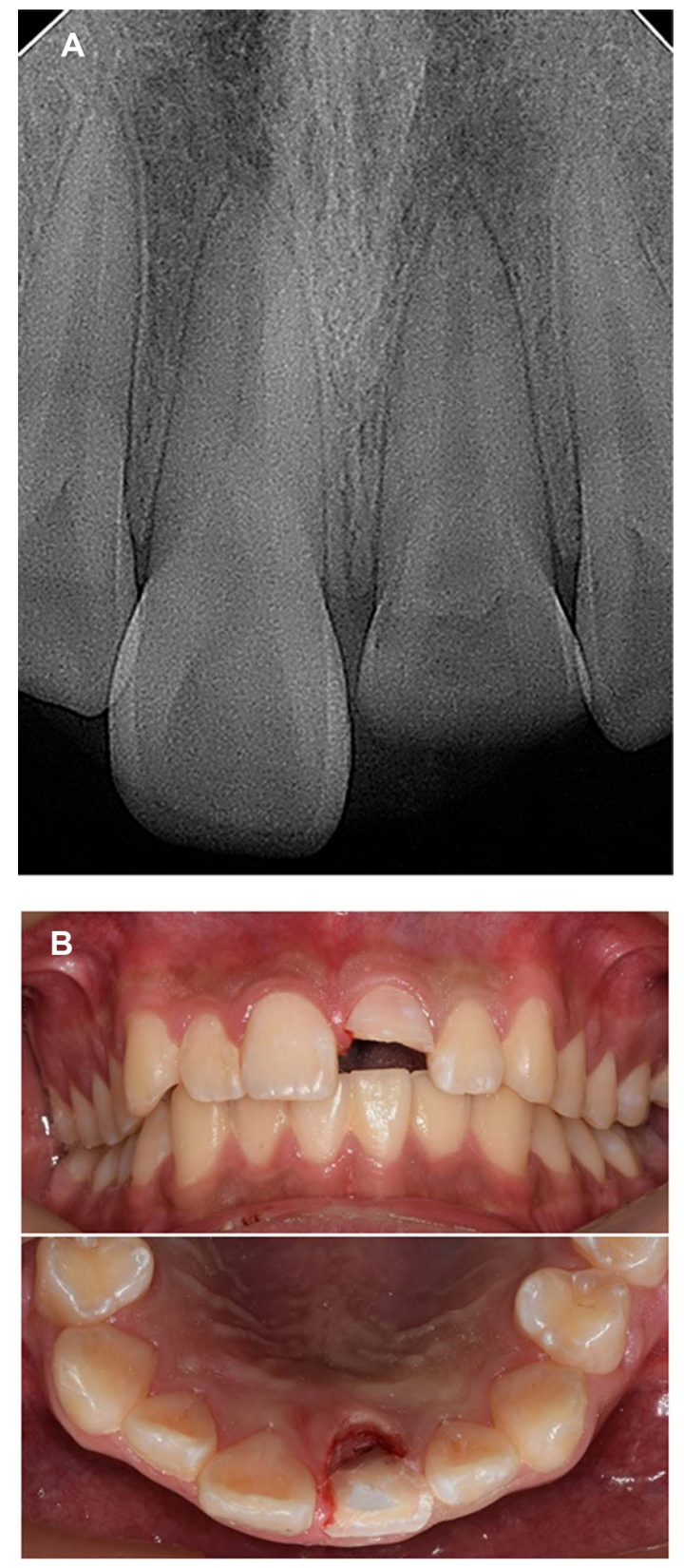

Fig. 1. (A) Periapical view and (B) intra-oral photographs at first visit.

후 $3.6 \mathrm{~mm}$ 의 정출량이 관찰되어 정출술을 종료하고 치아 의 유지를 위해 구개측에 고정식 유지장치를 장착하였다 (Fig. 5). 3개월, 6개월 및 12개월 정기검진 시 특별한 임 상적 증상 및 재발은 관찰되지 않았다.

\section{증례 2}

2016년 09월 본원에서 치근단형성술 진행중이던 11세 남아가 상악 좌측 중절치의 치관치근 파절을 주소로 내원 하였다. 내원 당시 임상 및 방사선학적 검사 상 구개측에 서 치은연상, 순측에서 치은연하 파절선이 관찰되어 치관 

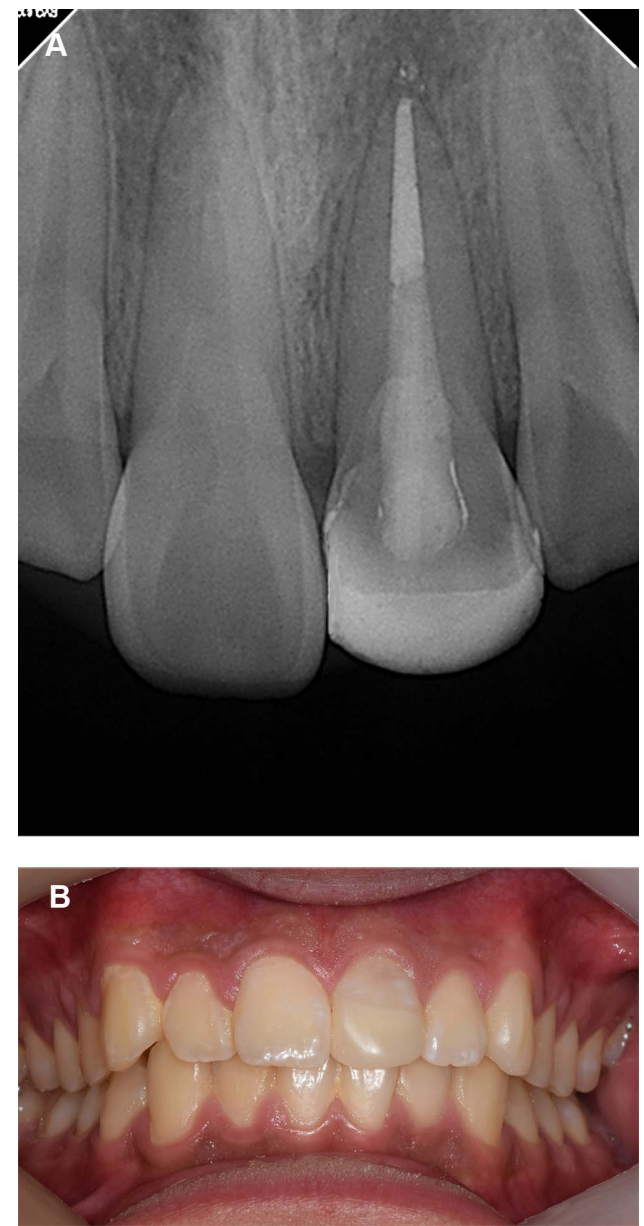

Fig. 2. (A) Periapical view and (B) intra-oral photographs after GP cone Filling and Resin build up. The resin build up was carried out on a temporary basis, which allows a more visible visualization of the amount of forced eruption.
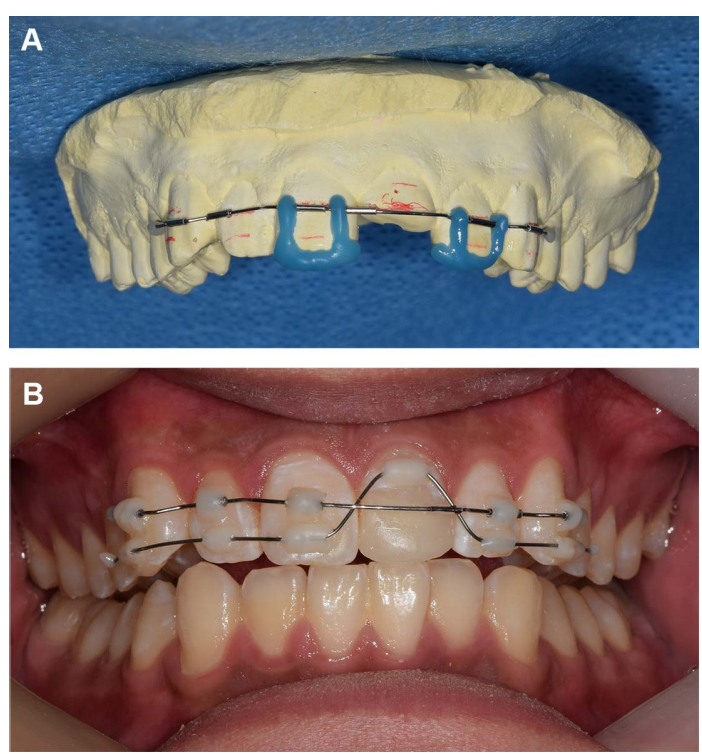

Fig. 3. Clinical procedure of Customized resin tube appliance. (A) Indirect bonding for passive bracketing and (B) intra-oral photographs after formation of a Customized resin tube.
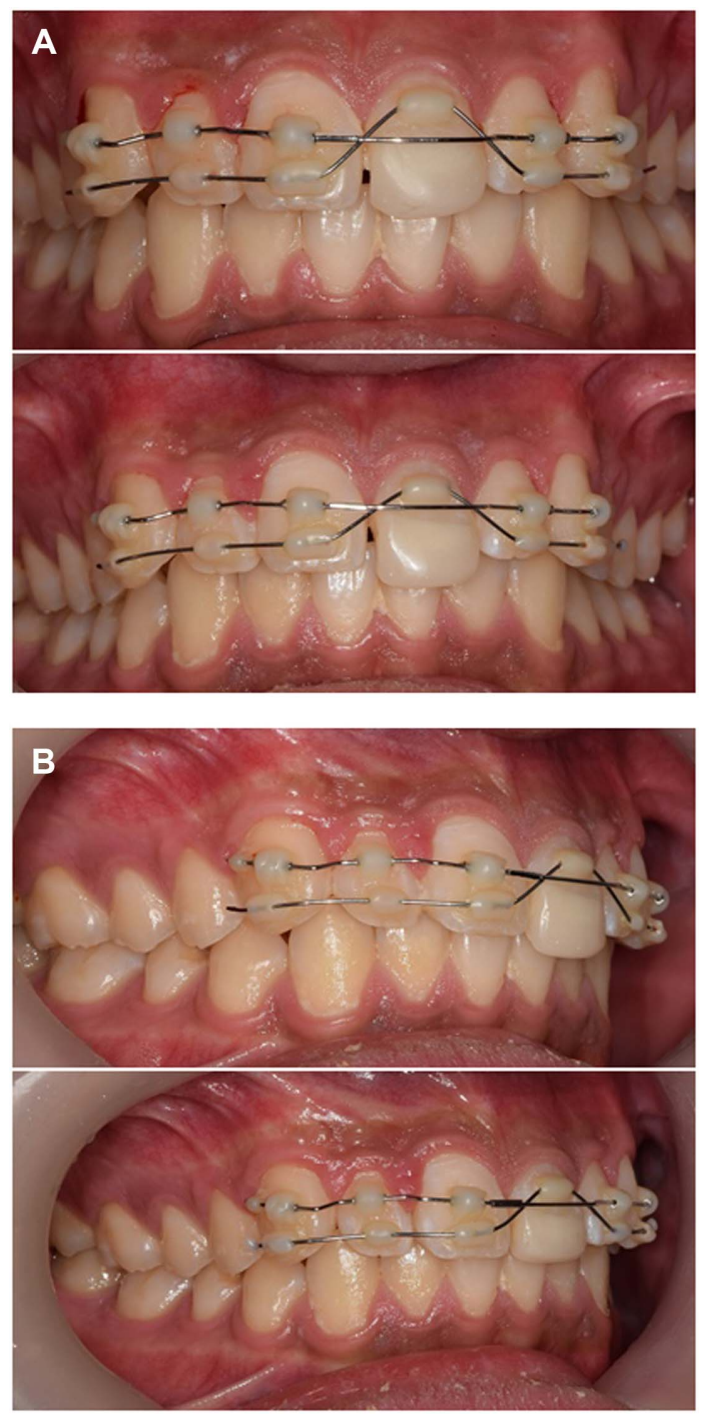

Fig. 4. Intra-oral photographs of (A) forced eruption procedure and (B) cutting of inicisal edge to prevent occlusal interference.

치근파절로 진단되었다(Fig. 6). 임시 치관심미수복술을 시 행한 후(Fig. 7) 증례1과 같은 방법으로 교정적 정출술을 시행하였다. 2 개월 후 $3 \mathrm{~mm}$ 의 정출량이 관찰되어 정출술 을 종료하고 정출된 치아의 유지를 위해 구개측에 고정식 유지장치를 장착하였다(Fig. 8). 3개월, 6개월 및 12개월 정기검진 시 특별한 임상적 증상 및 재발은 관찰되지 않 았다.

\section{교 찰}

통계학적으로 대부분의 외상은 성인기 이전인 소아 청 소년기에 발생되며 그로인해 외상 정도, 치아의 성숙도 및 협조도에 따라 치료법의 선택 및 행동조절의 어려움이 있 

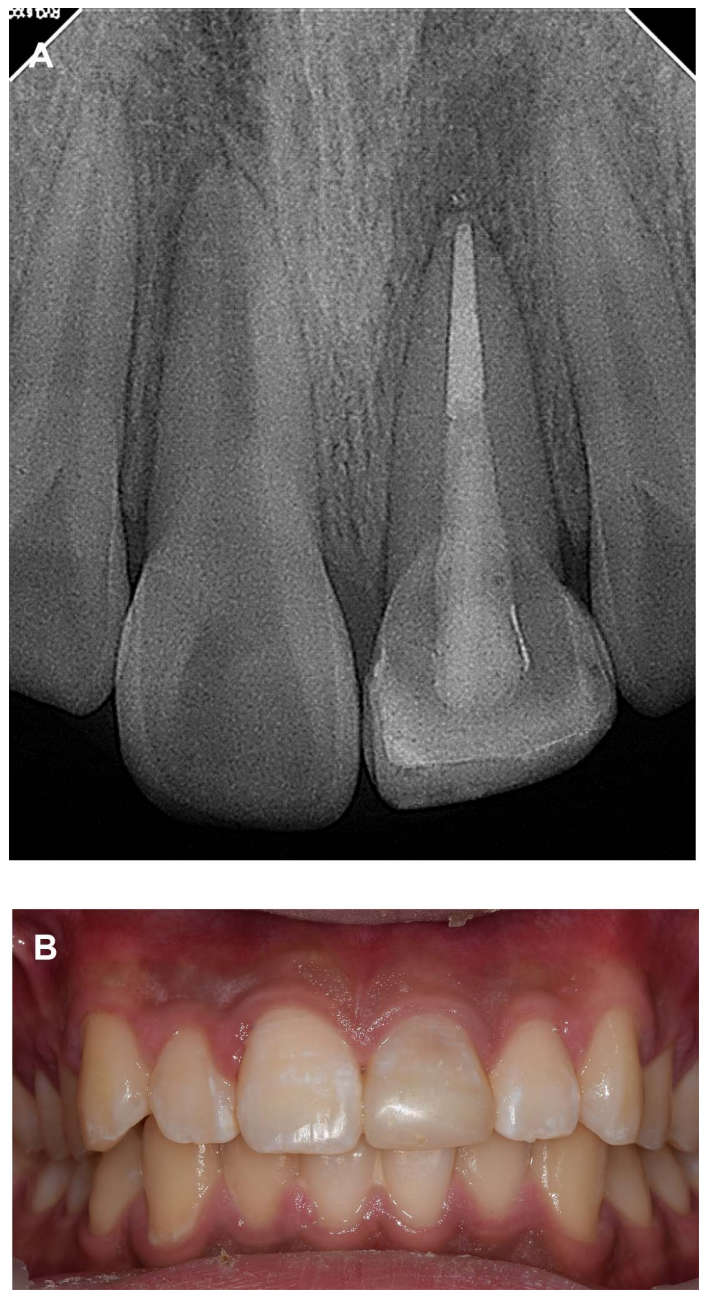

Fig. 5. (A) Periapical view and (B) intra-oral photographs after forced eruption was finished.

다[4]. 특히, 치관피근파절과 같이 파절선이 치은연하에 위 치하는 경우에는 수복 전에 생물학적 폭경의 유지를 위해 추가적인 치료가 필수적일 수 있다. 즉, 계획된 수복물이 생물학적 폭경을 침범할 위험이 있는 경우에는 이를 증가 시키기 위한 임상적 치관연장술이 고려되어야한다. 하지 만 모든 경우에 치관연장술이 가능한 것은 아니며 부적절 한 치관치근비율, 높은 이개부, 부적절한 치열궁관계, 인접 치의 치주조직 손상 및 심미적인 문제 등이 있는 경우에 는 비적응증으로 여겨진다[5].

비적응증에 해당되지 않고 치관연장술이 가능하다면 발 치를 시행하기 전에 다음과 같은 치료법들의 선택이 우선 시 되어야함을 명심해야 할 것이다.

첫 째, 충분한 연조직이 있어서 치은절제시 치조골노출 과 생물학적 폭경을 침범하지 않는 경우: 단순 치은절제술 또는 치은성형술로 처치가 가능하다 $[5,13]$. 치관연장술 중 가장 기본적인 치료법인 치은절제술은 치은의 치유와 생 리적 치은 형태를 갖는 수복이 가능하도록 하지만 상악 전
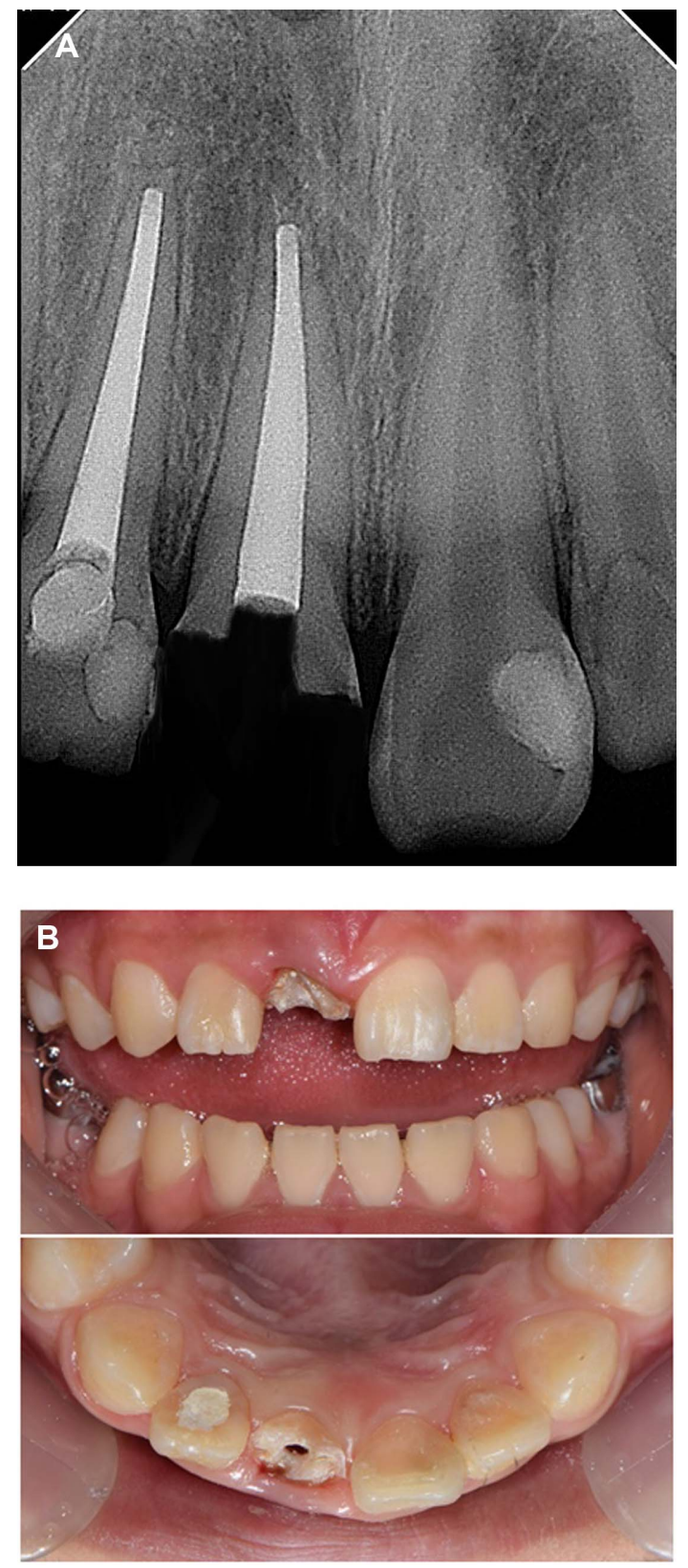

Fig. 6. (A) Periapical view and (B) intra-oral photographs at first visit.

치부와 같이 심미적으로 중요한 부위에서는 시행하지 않 는 것이 추천된다[3-5]. 그리고 골절제술 여부와 상관없이 연조직 절제술 후에 적당한 양의 각화치은이 항상 존재해 야 하는데 최소 $2 \mathrm{~mm}$ 의 각화치은 폭이 확보되는 것을 권 장한다[9]. 따라서 dentogingival complex와 각화치은이 충 분하여 연조직이 충분한 경우에만 외사절개를 통한 치은 절제술만으로 치료가 가능하다.

둘 째, 치조골노출이 예상되는 경우: 골절제술과 치은절 제술을 동반한다[5]. 즉, 각화치은은 충분하지만 dentogingival complex가 $3 \mathrm{~mm}$ 이하로 불충분하여 치은절제술만을 시행 

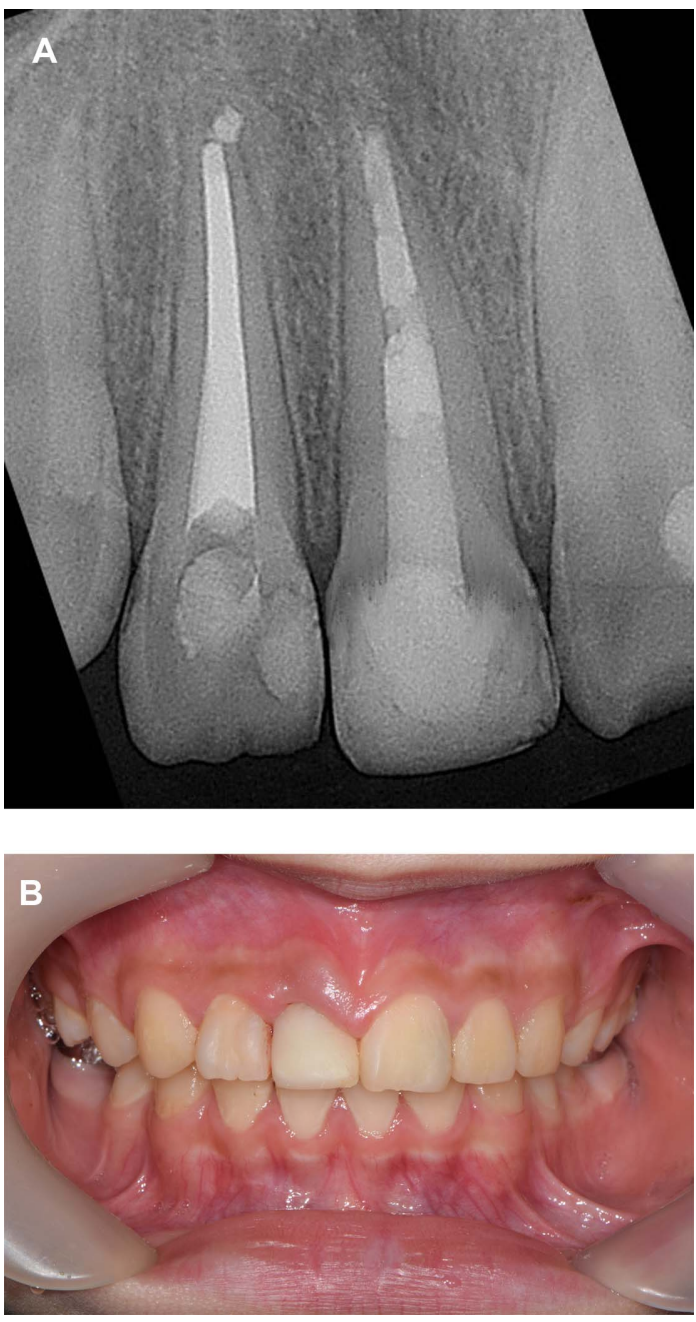

Fig. 7. (A) Periapical view and (B) intra-oral photographs after GP cone Filling and Resin build up. The resin build up was carried out on a temporary basis, which allows a more visible visualization of the amount of forced eruption.

하였을 때 생물학적 폭경의 침범, 치조골 노출이 예상되는 경우는 골삭제가 동반되어야 한다. 골절제술 시에는 판막 을 치관측으로 변위시켜 치주 조직의 보존을 최대화하고 골 절제술 후 치유가 완료되면 치은연의 수정이 가능하도 록 해준다[5]. 이와 같은 골절제술을 동반한 치은절제술은 외과적 치관 연장술시 가장 일반적인 술식이다. 하지만, 술 후에 인접치의 치조골이나 치은 변연과 현저한 차이가 발생할 수 있어 심미적으로 허용되지 않을 수 있다. 따라 서 대상치아가 1개뿐인 상악 전치부에서는 추천되지 않는 다. 또한 성장기 아동인 경우에는 치은절제술, 골삭제를 동반한 치관 연장술은 성장에 따른 치은의 형태 변화를 예 측하기가 어렵다는 한계가 있다.

셋 째, 부착치은이 부적절한 경우: 치료 술식에 제한을 갖게 되며 골절제술을 동반하거나 하지 않는 근단변위판 막술을 시행한다[5]. dentogingival complex 양과 무관하게
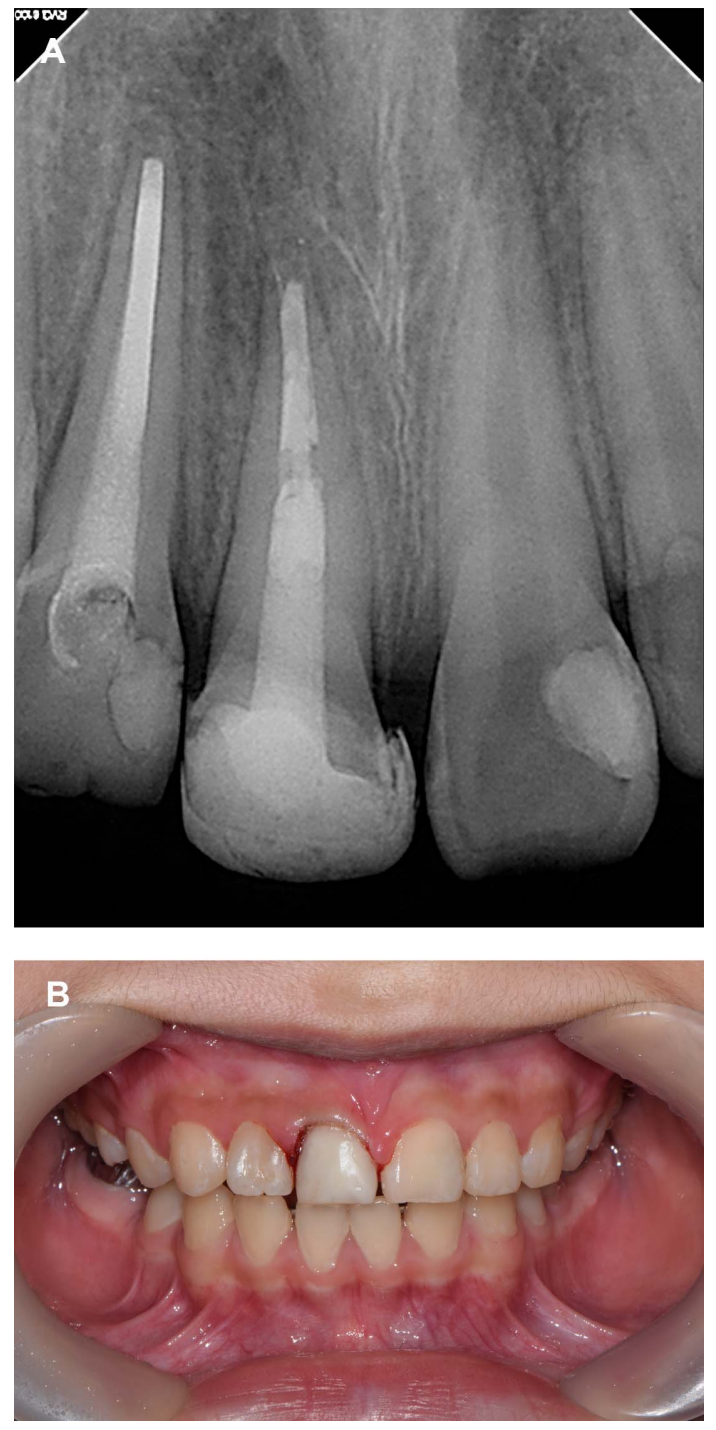

Fig. 8. (A) Periapical view and (B) intra-oral photographs after forced eruption was finished.

각화치은이 $2 \mathrm{~mm}$ 이하로 부족한 경우 외사절개를 통한 치은절제가 불가능하며 내사절개를 통해 근단변위판막술 을 통해 각화치은을 확보하는 것이 가장 중요하다.

이처럼 치관연장술은 치은절제술 및 골절제술을 통해 치관을 근단측으로 연장할 수 있다. 하지만 심미적으로 허 용되지 않는 위치인 경우에는 외과적 또는 교정적 정출술 을 통해 치관측으로 연장하는 것이 추천된다[8].

외과적 정출술은 판막을 거상하여 치아의 파절선과 치 조골의 관계를 확인한 후 치아를 탈구시켜 원하는 위치까 지 정출시키는 방법이다. 이 술식은 한 단계로 빠르고 간 단하게 시행할 수 있지만 시술시 치주인대 세포의 손상이 있을 수 있다는 단점이 있다[14-16]. 이러한 한계점과 술 후 합병증을 예방하기 위해 외과적 정출술 시행 시에는 잘 계획되고 제한된 탈구를 통해 치주인대의 생활력을 보존 
하고 기능적 치유가 가능하도록 하는 것이 중요하다 $[14,16]$. 기능적 치유는 치근흡수의 부재, 정상범위내의 동 요도, 방사선사진상 온전한 치조백선과 같은 지표를 통해 확인할 수 있다. 하지만 술식의 특성상 기구 조작 중 손상 가능성을 완전히 배제할 수 없어 술식 민감도가 높은 치 료법이다.

교정적 정출술은 교정력을 가하여 치아를 이동시킴으로 써 모든 부분의 치주인대에서 치조골정의 변연을 자극하 여 침착이 일어나게 하는 술식이다. 교정적 정출술을 통한 치관연장술은 해당 치아와 인접한 치아주위의 외과적 골 제거량이 과도할 때 유용하며 골 또는 치주조직 지지의 상 실을 일으키지 않아 보존적이며 본 증례와 같이 심미적으 로 중요한 전치부에서 우선적으로 선택될 수 있는 술식으 로 외과적 정출술에 비해 좀 더 생리적인 이동이 가능하 여 인접치의 손상을 피할 수 있게 한다[5,17]. 그리고 더 나은 치관치근 비율과 외과적 술식만 시행한 경우보다 더 욱 심미적인 결과를 제공한다. 하지만 긴 치료기간을 필요 로 하고 교정 장치의 부착 등으로 인해 환자에게 불편감 을 줄 수 있으며 치근이 근접하고 치간공극이 조기에 폐 쇄된 경우, 유착 또는 과백악질증으로 부가적 하중이 고정 원이 되는 치아의 함입을 야기시킬 경우, 수직적 치근 파절 의 경우에는 금기시 된다[17,18]. 또한 교정적정출술 시행 전에는 치근 길이, 치근 형태, 파절선의 위치, 치아의 중요 도, 환자의 연령 그리고 치료에 필요한 기간과 비용에 대한 환자의 이해도 등을 사전에 파악하는 것이 중요하다[17].

교정적 정출술의 방법에는 $15-30 \mathrm{~g}$ 의 정출력을 이용한 저속 정출술과 $50 \mathrm{~g}$ 이상의 정출력을 이용한 고속 정출술 이 있다 $[1,17]$. 저속 정출술은 치아 정출과 함께 치조골과 치은의 이동이 동시에 이루어져 교정적 정출술을 시행한 후, 생물학적 폭경 확보를 위한 외과적 처치가 필요하게 된다. 반대로 고속 정출술은 큰 정출력을 이용해 빠르게 치아를 이동시켜 치주조직의 치관측 이동이 동시에 발생 하지 않도록 하여 추가적인 골절제술 등의 외과적처치의 필요성을 줄여준다[4,19,20]. 생물학적 폭경 확보를 위한 교정적 정출술은 치주인대 주섬유를 최대한 확장시키고 새로 형성된 백아법랑경계 주변에 즉각적인 골형성이 일 어나지 않도록 하는 것이 중요하므로 고속 정출술이 추천 된다[19].

교정적 정출술은 통상적으로 가철식 장치와 고무줄 또 는 브라켓과 와이어를 이용하여 진행될 수 있는데[10] 가 철식 장치를 이용하는 경우에는 환자의 협조도에 영향을 많이 받게 되어 소아청소년기에 있는 환자들에게 사용 시 어려움이 있다. 추가로 장치파절에 의한 재제작으로 치료 기간이 장기화될 가능성이 있다. 다음으로, 인접한 2-4개 의 치아에 레진을 이용하거나 브라켓을 부착하여 와이어 를 고정한 후 power chain이나 elastic thread를 이용해 정
출력을 가하는 방법은 고정원으로 이용되는 인접치의 tipping 가능성을 피할 수 없다는 한계점이 있다. 그리고 브라켓을 부착할 경우 심미적이지 않으며 구강위생관리가 어렵다는 단점이 있다.

본 증례에서는 이를 극복하기 위한 방법으로 최근에 부 분교정에 많이 사용되는 $\mathrm{MTA}$ 를 사용하였다. 이는 전치부 에 미약한 정중이개가 있거나 돌출된 경우, 부분적으로 치 열이 틀어진 경우, 장치 노출을 꺼리는 경우, 시간적 여유 가 부족한 경우에 고려할 수 있는 전치부 부분 교정 방법 으로 $3 \mathrm{~mm}$ 정도 크기의 미니튜브를 사용해 이물감이나 통증이 거의 없고 빠르면 6주, 평균 3-6개월 정도로 교정 기간이 짧다[11]. 그리고 기존 브라켓에 비해 탈락률이 낮 으며 심미적이다. 또한 치아이동 중 마찰저항이 적어 교정 치료 시 발생할 수 있는 치근흡수, 치주손상, 원치 않은 치 아이동 등 다양한 부작용을 방지할 수 있다는 장점이 있 다[11]. 이런 장점들은 본 증례에서 더 간편하고 빠르게 교 정적 정출술의 진행할 수 있도록 해주었다.

하지만 시판되고 있는 MTA는 고가여서 이를 대체할 만 한 방법들이 제안되었다. 그 예 중 하나가 $3 \mathrm{~mm}$ 길이로 절단한 시린지 팁을 사용하는 것이다. 튜브로 사용할 수 있도록 니들을 절단하고 연마하는 과정이 까다롭지만 레 진으로 피개하면 심미성을 유지할 수 있으며 구하기 쉽고 저렴하여 사용이 용이하다. 다른 방법으로는 elastic thread 를 사용해 튜브를 대신할 수 있는 홀을 직접 형성하는 방 법이 있다. 본원에서 사용되고 있는 방법으로 약 $0.7 \mathrm{~mm}$ 의 직경을 가진 elastic thread 안에 형광 낚시줄을 끼워 넣어 가시화한 뒤, 이를 튜브 대용으로 이용하는 방법이다. 본 증 례에서는 두 가지 Modified MTA를 통해 Customized resin tube를 형성하여 치료한 케이스를 소개하였다.

교정적 정출술이 완료된 후에는 외상성교합력의 작용여 부에 대한 평가가 필요하다. 그리고 교정적 정출술이 완료 되고 유지기간을 갖는 것은 필수적이다. 교정적 정출이 완 료된 후, 유지기간에 대해서는 Heithersay와 Ingber는 2개 월을 추천하였으며 Guilford 등은 3-6개월의 유지기간을 추천하였다[21-23]. 또한 Dolt는 재발을 막기 위해 정출량 $1.0 \mathrm{~mm}$ 당 8-12주의 유지기간이 필요하다고 보고하였다 [24]. 여전히 유지 기간에 대해서는 논문들마다 조금씩 상 이한 편이나 보통 정출을 시행한 기간 또는 약 2 개월의 유 지기간이 사용되고 있다. 여러 문헌에서 재발을 막고 유지 기간을 감소시키기 위한 상치조섬유 절개의 필요성을 강 조하였다[25-27]. 주요 치주섬유들은 유지기간 동안 재배 열되지만 상치조섬유는 장기간동안 신장된 채로 남아있어 이러한 섬유를 절제해주는 것이 재발을 예방하기 위해 중 요하게 된다. 하지만 치료가 끝났음에도 불구하고 지속적 으로 검진 시 유착 또는 외흡수와 내흡수 등 치근의 흡수 가 지속되어 더 이상 유지가 불가능할 때는 발거를 고려 
해야할 수 있지만 성장기 동안에는 치조골 폭경 유지를 위 해 발거를 뒤로 미루거나 치관절제술(decoronation)을 시 행하여 시기를 늦추는 것이 중요하다.

$\mathrm{MTA}$ 를 이용한 교정은 상대적으로 짧은 치료기간과 심 미적인 측면에서 소아환자와 보호자 모두에게 만족할만한 치료방법이 될 수 있다. 이와 같은 장점들을 고려하여 다 양한 증례에서 활용한다면 큰 이점을 얻을 수 있을 것이 다. 본 증례에서는 MTA의 변형 형태인 Customized resin tube appliance를 이용해 교정적 정출술을 시행하였다. 이 는 환아 협조도를 따로 필요로 하지 않으며 좀 더 심미적 으로 빠르고 안전하게 원하는 정출을 시행할 수 있었다는 점 에서 효과적인 방법이라고 생각된다.

\section{감사의 글}

This study was supported by research fund from Chosun University Dental Hospital, 2018.

\section{Conflict of Interest}

The authors declare that they have no competing interests.

\section{ORCID}

$\begin{array}{ll}\text { So-Young Kim } & 0000-0002-7302-5896 \\ \text { Sang-Ho Lee } & 0000-0003-2513-6871 \\ \text { Nan-Young Lee } & 0000-0002-4738-9389 \\ \text { Myeong-Kwan Jih } & 0000-0001-9579-076 \text { X }\end{array}$

\section{References}

1. Mittal R, Gupta S, Singla A, Gupta A. Managing subgingival fracture by multi-disciplinary approach: Endodontics-forced orthodontic extrusion and prosthetic rehabilitation. Saudi Endod J 2013;3:82-86. doi: 10.4103/ 1658-5984.118157.

2. Tapias MA, Jiménez-García R, Lamas F, Gil AA. Prevalence of traumatic crown fractures to permanent incisors in a childhood population: Móstoles, Spain. Dent Traumatol 2003;19:119-122. doi: 10.1034/j.1600-9657. 2003.00141.x.

3. Dede DÖ, Tunç EŞ, Güler AU, Yazicioğlu S. Multidisciplinary approach to a subgingivally fractured incisor tooth: A case report. JDS 2017;12:190-194. doi: 10.1016/j.jds.2012.
09.019 .

4. Koyuturk AE, Malkoc S. Orthodontic extrusion of subgingivally fractured incisor before restoration. A case report: 3-years follow-up. Dent Traumatol 2005;21:174178. doi: 10.1111/j.1600-9657.2005.00291.x.

5. Gupta G, Gupta R, Gupta N, Gupta U. Crown Lengthening Procedures- A Review Article. IOSR-JDMS 2015;14:2737. doi: 10.9790/0853-14412737.

6. Nugala B, Kumar BS, Sahitya S, Krishna PM. Biologic width and its importance in periodontal and restorative dentistry. J Conserv Dent 2012;15:12-17. doi: 10.4103/ 0972-0707.92599.

7. Fidel SR, Fidel-Junior RA, Sassone LM, Murad CF, Fidel RA. Clinical management of a complicated crownroot fracture: a case report. Braz Dent J 2011;22:258262. doi: 10.1590/S0103-64402011000300014.

8. Saito CT, Guskuma MH, Gulinelli JL, Sonoda CK, Garcia-Júnior IR, Filho OM, Panzarini SR. Management of a complicated crown-root fracture using adhesive fragment reattachment and orthodontic extrusion. Dent Traumatol 2009;25:541-544. doi: 10.1111/j.1600-9657.2009. 00811.x.

9. Lang NP, Löe H. The relationship between the width of keratinized gingiva and gingival health. J Periodontol 1972;43:623-627. doi: 10.1902/jop.1972.43.10.623.

10. Mandel RC, Binzer WC, Withers JA. Forced eruption in restoring severely fractured teeth using removable orthodontic appliances. J Prosthet Dent 1982;47:269-274. doi: 10.1016/0022-3913(82)90155-X.

11. Hwang HS, Jeon HR, Kim SP, Kim WS, Lee GH. A new orthodontic appliance for rapid anterior alignment in adults; Mini-Tube Appliance (MTA). J Korean Dent Assoc 2011;49:398-409.

12. Kim HI, Lim SH, Gang SN. Orthodontic treatment using mini-tube appliances and customized resin domes using 3D CAD design. Oral Biol Res 2016;40:134-142. doi: 10.21851/obr.40.3.201609.134.

13. Sonick M. Esthetic crown lengthening for maxillary anterior teeth. Compend Contin Educ Dent 1997;18:807812, 814-816, 818-819.

14. Calişkan MK, Türkün M, Gomel M. Surgical extrusion of crown-root-fractured teeth: a clinical review. Int Endod J 1999;32:146-151. doi: 10.1046/j.1365-2591.1999.00199.x.

15. Kahnberg KE. Intraalveolar transplantation of teeth with crown-root fractures. J Oral Maxillofac Surg 1985;43:38-42. doi: 10.1016/S0278-2391(85)80011-2.

16. Özer SY, Uysal İ, Bahşi E. Surgical extrusion of a complete crown fractured tooth: A case report. Int Dent Res 2011;2:70-74. doi: 10.5577/intdentres.2011.vol1.no2.6.

17. Bach N, Baylard JF, Voyer R. Orthodontic extrusion: periodontal considerations and applications. J Can Dent Assoc 2004;70:775-780.

18. Nappen DL, Kohlan DJ. Orthodontic extrusion of pre- 
molar teeth: an improved technique. J Prosthet Dent 1989;61:549-554. doi: 10.1016/0022-3913(89)90274-6.

19. Bondemark L, Kurol J, Hallonsten AL, Andreasen JO. Attractive magnets for orthodontic extrusion of crownroot fractured teeth. Am J Orthod Dentofacial Orthop 1997;112:187-193. doi: 10.1016/S0889-5406(97)70245-2.

20. Zyskind K, Zyskind D, Soskolne WA, Harary D. Orthodontic forced eruption: case report of an alternative treatment for subgingivally fractured young permanent incisors. Quintessence Int 1992;23:393-399.

21. Heithersay GS. Combined endodontic-orthodontic treatment of transverse root fractures in the region of the alveolar crest. Oral Surg Oral Med Oral Pathol 1973; 36:404-415. doi: 10.1016/0030-4220(73)90220-X.

22. Ingber JS. Forced eruption: Part I. A method of treating isolated one and two wall infrabony osseous defectsrationale and case report. J Periodontol 1974;45:199-
206. doi: 10.1902/jop.1974.45.4.199.

23. Guilford HJ, Grubb TA, Pence DL. Vertical extrusion: a standardized technique. Compend Contin Educ Dent 1984;5:562-567.

24. Dolt AH, Robbins JW. Altered passive eruption: an etiology of short clinical crowns. Quintessence Int 1997; 28:363-372.

25. Kozlovsky A, Tal H, Lieberman M. Forced eruption combined with gingival fiberotomy. A technique for clinical crown lengthening. J Clin Periodontol 1988;15:534538. doi: 10.1111/j.1600-051X.1988.tb02125.x.

26. Shyammohan A. Forced Eruption: An Adjunct to Prosthodontic Treatment Planning. Indian J Stomatal 2011;2:260262.

27. Bajaj P, Chordiya R, Rudagi K, Patil N. Multidisciplinary approach to the management of complicated crown-root fracture: a case report. J Int Oral Health 2015;7:88-91. 